\title{
Profil Number Sense Siswa Berprestasi Pada Materi Pecahan
}

\author{
Nurul Hidayati ${ }^{\text {1*, Al Kusaeri }}$, Sofyan Mahfudy * \\ *Affiliasi: Universitas Islam Negeri Mataram
}

Kata kunci :

number sense; siswa berprestasi; pecahan

\begin{abstract}
A b s trak
Kepekaan bilangan (number sense) merupakan aspek yang harus dikuasai dengan baik oleh setiap siswa yang belajar matematika, sebab dapat membantu pemahaman mereka terhadap makna bilangan dan operasinya dengan lebih baik. Di sisi lain, siswa berprestasi di sekolah terkadang memiliki kemampuan matematika yang kurang baik. Penelitian ini bertujuan untuk menganalisis dan mendeskripsikan profil number sense siswa berprestasi pada materi pecahan kelas VII sekolah menengah pertama. Penelitian ini menggunakan pendekatan kualitatif jenis deskriptif. Pengambilan subjek menggunakan teknik purposive sampling, dengan jumlah subjek 3 siswa berprestasi di kelas VII. Instrumen soal tes number sense (TNS) dan pedoman wawancara dikembangkan peneliti. Prosedur pengumpulan data menggunakan tes dan wawancara. Analisis data menggunakan tiga tahap menurut teori Miles dan Huberman dengan mengacu kepada setiap komponen number sense beserta indikatornya. Hasil penelitian ini menunjukkan bahwa kemampuan number sense siswa berprestasi di sekolah menengah pertama pada materi pecahan cukup baik, terutama pada aspek memahami konsep bilangan, representasi urutan bilangan, perhitungan, dan strategi menghitung. Namun demikian, beberapa indikator number sense belum terpenuhi, yaitu menunjukkan pecahan yang terdapat di antara dua pecahan serta menggambarkannya pada garis bilangan. Siswa berprestasi juga belum baik dalam hal pengoperasian bilangan dan pernyataan yang setara.
\end{abstract}

${ }^{1}$ Corresponden to author: Program Studi Tadris Matematika-FTK UIN Mataram, Jl. Gajah Mada Jempong, Indonesia. (83116), email address. hidayatiuyun237@gmail.com, email address; alkusaeri@uinmataram.ac.id, email address; sofyan mahfudy@uinmataram.ac.id 
Keywords: number sense; student achievement; fraction

\begin{abstract}
A bstract
Number sense (number sense) is an aspect that must be mastered well by every student who studies mathematics, because it can help their understanding of the meaning of numbers and their operations better. On the other hand, students who excel at school sometimes have poor math skills. This study aims to analyze and describe the number sense profile of outstanding students in junior high school class VII fraction material. This research uses a descriptive qualitative approach. Taking the subject using purposive sampling technique, with the number of subjects 3 outstanding students in class VII. The instrument for the number sense test (TNS) and interview guidelines was developed by the researcher. Data collection procedures using tests and interviews. Data analysis used three stages according to Miles and Huberman's theory by referring to each number sense component and its indicators. The results of this study indicate that the number sense ability of outstanding students in junior high school on fractions is quite good, especially in the aspects of understanding the concept of numbers, representation of number sequences, calculations, and counting strategies. However, several number sense indicators have not been fulfilled, namely showing the fraction that is between two fractions and describing it on the number line. Outstanding students are also not good at operating numbers and equivalent statements.
\end{abstract}

\section{Pendahuluan}

Mempelajari matematika pada dasarnya adalah proses mengolah angka dan bilangan. Ketika belajar matematika hanya fokus kepada perhitungan bilangan, maka akan menyebabkan seni dan kebermaknaan matematika menjadi hilang. Terutama kebermaknaan pada konsep bilangan dan operasinya. Matematika tidak hanya sekedar ilmu pemahaman terhadap bilangan dan algoritmanya, melainkan pemahaman makna dari bilangan itu (Mufidah, 2017). Pemahaman makna dari bilangan itu artinya memahami konsep bilangan, operasi bilangan, sifat-sifat bilangan, pola bilangan, dan hubungan di dalamnya dengan baik. Oleh karena itu, pemahaman tentang bilangan itu penting. Pemahaman tentang bilangan juga merupakan faktor utama keberhasilan dalam menyelesaikan berbagai soal matematika. Pemahaman tentang bilangan dan operasinya serta kemampuan dan kecenderungan untuk menggunakan pemahaman ini dengan cara yang fleksibel untuk membuat penilaian matematis serta pengembangan strategi dalam menghadapi masalah-masalah berkaitan dengan bilangan dan operasinya inilah yang kemudian disebut sebagai kemampuan kepekaan bilangan atau number sense (McIntosh, Reys, \& Reys, 1992).

Penelitian terdahulu yang mengkaji kemampuan number sense siswa telah banyak dilakukan (Gulbacgci \& Sengul, 2012; Yapici \& Altay, 2017; Hidayat \& Budiarto, 2014; Tonra, 2018; Witri, Putra \& Nurhanida, 2015; Putrawangsa \& Hasanah, 2018), namun 
belum banyak penelitian yang fokus mengkaji kemampuan number sense pada siswa berprestasi. Siswa berprestasi dalam hal ini adalah siswa berprestasi secara umum atau siswa yang mendapat juara umum, tidak hanya khusus berprestasi di mata pelajaran matematika saja karena belum tentu semua siswa berprestasi baik dalam mata pelajaran matematika. Jannah (2014) menyatakan bahwa terdapat siswa dengan IQ tinggi mendapat hasil belajar matematika rendah dengan faktor penyebab di antaranya adalah 1) siswa kurang tertarik dengan pelajaran matematika, 2) guru kurang mampu menguasai kelas, terlalu monoton dalam menggunakan metode pembelajaran, dan 3) pihak sekolah belum mampu untuk menyediakan fasilitas yang memadai untuk pembelajaran. Hal ini tentu saja menarik untuk diungkap bagaimana kemampuan number sense pada siswa berprestasi.

McIntosh, Reys, \& Reys (1992) merumuskan komponen number sense menjadi enam komponen yang antara lain: (1) pemahaman dan penggunaan arti dan ukuran bilangan (understanding and use of meaning and size of numbers), (2) pemahaman dan pengunaan bentuk setara dan representasi dari bilangan (understanding and use of equivalent forms and representations of numbers), (3) pemahaman makna dan dampak operasi (understanding the meaning ang effect of operation), (4) pemahaman dan penggunaan ekspresi setara (understanding and use of equivalent expressions), (5) komputasi dan penggunaan strategi yang tepat (computing and counting strategies) dan (6) penggunaan patokan dalam (measurement benchmarks).

Selanjutnya McIntosh (1992) menyatakan bahwa untuk mengukur kemampuan number sense anak hanya menggunakan lima komponen number sense sebagai indikator dalam membuat soal. Sedangkan untuk enam komponen number sense digunakan untuk mengukur anak yang memiliki kemampuan atau jenjang pendidikan yang lebih tinggi. Adapun lima komponen number sense tersebut adalah konsep bilangan, representasi urutan bilangan, pengaruh dari pengoperasian bilangan, pernyataan yang setara dan perhitungan dan strategi menghitung. Komponen ini sering digunakan peneliti untuk menganalisis kemampuan number sense siswa.

Dengan diungkapnya kemampuan number sense pada siswa berprestasi, maka dapat membantu guru dalam menggunakan konsep atau strategi mengajar yang menunjang kemampuan number sense siswa. Sebagaimana salah satu manfaat number sense yang dikemukakan para peneliti beranggapan bahwa number sense sangat penting untuk dikembangkan di sekolah karena siswa membutuhkannya sebagai modal dasar yang positif dalam rangka untuk mengembangkan konsep diri yaitu keyakinan positif dan sikap senang terhadap matematika (Arhamni, Johar, \& Abidin, 2015).

\section{Metode}

Penelitian ini menggunakan pendekatan kualitatif jenis deskriptif. Sumber data dari penelitian ini adalah siswa kelas VII sekolah menengah pertama. Data yang akan dikumpulkan dalam penelitian ini meliputi: 1) data siswa berprestasi (juara umum) dan hasil belajar matematika yang mereka peroleh, 2) data hasil penyelesaian soal-soal number sense, dan 3) transkip wawancara. Penentuan subjek atau informan pada penelitian ini 
menggunakan teknik sampling yaitu purposive sampling number sense dengan kriteria subjek adalah siswa berprestasi di sekolah dan komunikatif dalam menyampaikan ide dan pendapatnya. Adapun penentuan siswa berprestasi diambil dari 10 besar siswa yang mendapatkan juara umum di semester ganjil kelas VII. Pada tahap pemilihan subjek, 10 siswa tersebut akan diberikan tes number sense (TNS) kemudian di pilih 3 siswa yang jawabannya paling baik sebagai subjek penelitian untuk diwawancara. instrumen yang digunakan adalah tes berupa soal uraian dan dan pedoman wawancara. Setelah data terkumpul, akan dilalakukan analisis data menggunakan tiga tahapan menurut Miles dan Huberman, yaitu reduksi data, penyajian data, dan penarikan simpulan (Miles Huberman, \& Saldana, 2014).

Soal TNS yang diberikan kepada subjek dalam penelitian ini terdiri dari satu masalah (problem) yang diikuti dengan 4 buah pertanyaan. Soal diadopsi dari penelitian terdahulu dan dikembangkan oleh peneliti. Soal TNS divalidasi oleh ahli yaitu dosen dari Program Studi Tadris Matematika UIN Mataram dengan menggunakan validasi isi karena instrumen dalam penelitian ini berbentuk tes. Validasi ini bertujuan untuk untuk menghasilkan data yang valid yaitu data yang sesuai dengan keadaan yang sebenarnya (Widoyoko, 2014). Soal TNS dalam penelitian ini adalah sebagaimana tersaji di bawah ini.

\section{Soal Tes Number Sense (TNS)}

Bu Tina memiliki $2 \mathrm{~kg}$ tepung. Ia akan membuat 20 buab roti yang memerlukan bahan 1/2 kg tepung dan 10 buah bolu yang memerlukan bahan 1/4 kg tepung. Tentukanlab:

1. Manakah di antara roti dan bolu yang lebih banyak menghabiskan tepung?

2. Letakekanlah $1 / 2 \mathrm{~kg}$ dan $1 / 4 \mathrm{~kg}$ pada garis bilangan!

3. Berapakah sisa tepung ibu Tina?

4. Jika roti tersebut dipotong $1 / 2$ bagian setiap satu buah roti dan bolu dipotong $1 / 4$ setiap satu buah bolu. Apakah jumlah potongan roti dan bolu sama?

Adapun komponen dan indikator untuk mengukur kemampuan number sense siswa pada materi pecahan pada penelitian ini menggunakan lima komponen menurut McIntosh, dkk (1992) dan indikator yang telah disusun oleh Mufidah (2017) yang terangkum dalam Tabel 1.

Tabel 1. Komponen dan indikator kemampuan number sense pada materi pecahan

\begin{tabular}{lll}
\multicolumn{1}{c}{ Komponen } & \multicolumn{1}{c}{ Indikator } \\
\hline Konsep bilangan & 1. Menunjukkan nilai tempat bilangan pecahan atau desimal. \\
& 2. Membandingkan nilai dua pecahan atau desimal. \\
& 3. Mengurutkan pecahan dan desimal. \\
4. Menunjukkan terdapat pecahan atau desimal lain antara dua
\end{tabular}




\begin{tabular}{|c|c|}
\hline & \\
\hline $\begin{array}{l}\text { Representasi } \\
\text { bilangan }\end{array}$ & $\begin{array}{l}\text { 1. Menyatakan pecahan atau desimal ke bentuk yang senilai } \\
\text { atau ekuivalen. } \\
\text { 2. Menentukan letak pecahan dan desimal dalam garis } \\
\text { bilangan. } \\
\text { 3. Menyatakan pecahan dalam wilayah yang diarsir, gambar, } \\
\text { dan sejenisnya. }\end{array}$ \\
\hline $\begin{array}{l}\text { Pengaruh dari } \\
\text { pengoperasian } \\
\text { bilangan }\end{array}$ & $\begin{array}{l}\text { 1. Mengemukakan akibat dari operasi pada dua bilangan yang } \\
\text { melibatkan pecahan maupun desimal. } \\
\text { 2. Menilai apakah bilangan sebagai hasil operasi yang diperoleh } \\
\text { masuk akal. }\end{array}$ \\
\hline $\begin{array}{l}\text { Pernyataan yang } \\
\text { setara }\end{array}$ & $\begin{array}{l}\text { 1. Mengenal dua pernyataan matematika yang setara. } \\
\text { 2. Menentukan pernyataan matematika lain yang setara dengan } \\
\text { pernyataan matematika yang diberikan } \\
\text { 3. Memanipulasi atau menyederhanakan pernyataan } \\
\text { matematika yang diberikan ke bentuk yang setara untuk } \\
\text { mempermudah mendapatkan solusi yang diinginkan }\end{array}$ \\
\hline $\begin{array}{l}\text { Perhitungan dan } \\
\text { strategi menghitung }\end{array}$ & $\begin{array}{l}\text { 1. Menggunakan strategi (estimasi, menghitung di kertas, } \\
\text { perhitungan mental) yang efektif dalam menyelesaikan soal } \\
\text { matematika. }\end{array}$ \\
\hline
\end{tabular}

Berdasarkan komponen dan indikator kemampuan number sense pada Tabel 1, peneliti menggunakan lima komponen dan tiga belas indikator sebagai tolak ukur kemampuan number sense siswa berprestasi pada materi pecahan. Analisis akan dilakukan berdasarkan semua indikator dari setiap komponen.

\section{Hasil dan Pembahasan}

Pada bagian ini akan disajikan profil number sense siswa berprestasi sesuai dengan analisis dan temuan data. Tidak semua data hasil penelitian akan disajikan dalam artikel ini, namun dipilih data yang representatif yang mewakili tiap komponen dan indikator kemampuan number sense sebagaimana Tabel 1.

\section{Konsep bilangan}

Berikut ini adalah hasil penyelesaian soal 1 dan cuplikan wawancara S1, S2, dan S3 pada aspek kemampuan memahami konsep bilangan. 


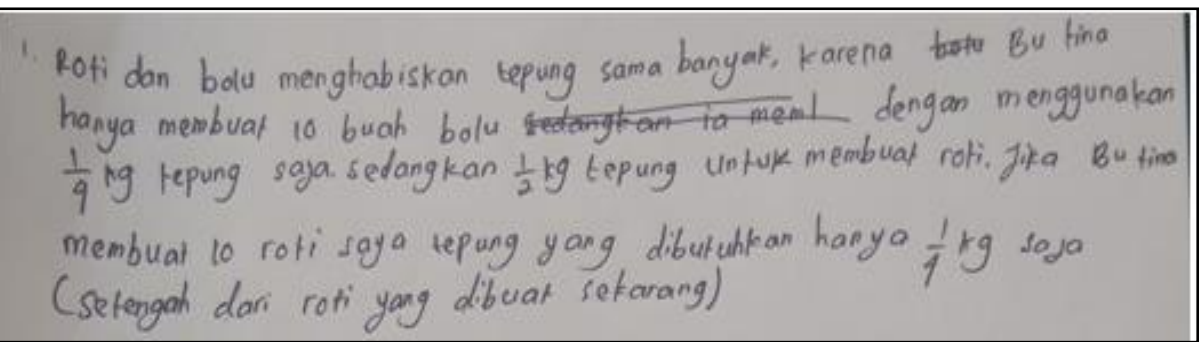

Gambar 1. Jawaban S1 terhadap soal 1

Cuplikan transkrip wawancara terhadap $S 1$ terkait soal 1

P : "Kenapa adik menjawab pembuatan roti dan bolu menghabiskan tepung sama banyak?"

S1 : "Karena bu Tina membuat 20 roti menggunakan 1/2 k.g tepung, sehingga jika dia membuat 20 bolu juga akan menghabiskan 1/2 kg tepung karena membuat 10 bolu menghabiskan 1/4 kg tepung"

$P$ : "Dari mana adik mengetahui 1/2 lebih besar dari 1/4?"

S1 : "Cuma lihat saja kak"

$P$ : "Cuma lihat saja dik?"

S1 : "Iya, tapi sebenarnya bisa pakai desimal."

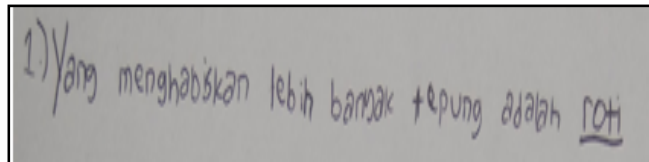

Gambar 2. Jawaban S1 terhadap soal 1

Cuplikan transkip wawancara terhadap S2 terkait soal 1

$P$ : "Kenapa adik menjawab roti lebih banyak menghabiskan tepung?"

S2: "Karena roti menghabiskan 1/2 kg dari $2 \mathrm{~kg}$ tepung yang sudah ada sedangkan bolu menghabiskan $1 / 4$.

$P$ : "Dari mana adik tabu lebih besar 1/2?"

S2: "Karena 1 itu dibagi 1/2, kalau didesimalkan jadinya 0,5 dan 1/4 itu 0,25. 0,5 itu mendekati angka 1 karena itu 0, 5 lebih besar."

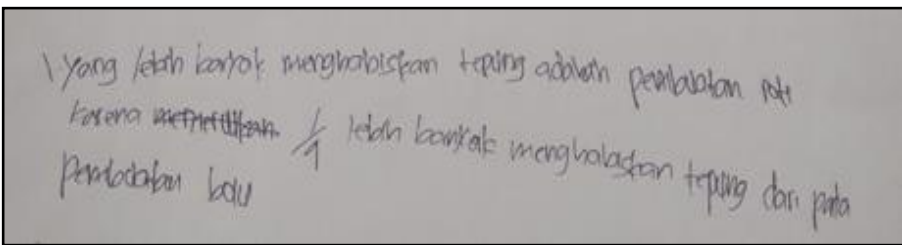

Gambar 3 Jawaban S3 terhadap soal 1

Cuplikan transkip wawancara terbadap $S 3$ terkait soal 1

$P$ : "Bagaimana adik mengetabui $1 / 2$ itu lebib besar dari 1/4?" 
S3 : "Menggunakan tanda lebih besar kak."

$P$ : "Maksud kakak melihatnya dari sisi mana? Misalkan mengubah ke bentuk desimalkah atan ke bentuk yang lain."

S3 : "Iya kak, bisa sib diubah ke desimal."

$P$ : "Lalu, adik melihatnya dari sisi mana?"

S3: "Ini kan 1/2 sama 1/4. Misalnya dijumlabkan 1/4 dan 1/2 bedanya saja 1/4. Jadi 1/4 ditambah 1/4 sama dengan 1/2."

Pada komponen pemahaman terhadap konsep bilangan ini, S1 dapat: a) menunjukkan nilai tempat dan bilangan pecahan atau desimal dengan memahi arti pecahan yaitu bilangan yang lebih kecil dari bilangan aslinya dan relatif besaran pecahan, b) membandingkan nilai dua pecahan atau desimal dengan cara merubah pecahan ke bentuk desimal, c) mengurutkan pecahan dengan merubah pecahan ke bentuk desimal, dan juga dengan mencari pecahan lain yang senilai dengan penyebut yang sama. Namun, S1 belum dapat menunjukkan terdapat pecahan lain antara dua pecahan atau desimal karena dia melihat dari urutan pembilangnya setelah menyamakan penyebut terlebih dahulu.

Pada komponen ini, S2 sudah dapat: a) menunjukkan nilai tempat dan bilangan pecahan atau desimal dengan memahami arti pecahan dan relatif besaran pecahan, b) membandingkan nilai dua pecahan dengan mengubah ke bentuk desimal terlebih dahulu, c) mengurutkan pecahan dengan mengubah ke bentuk desimal juga, d) menunjukkan terdapat pecahan lain antara dua pecahan atau desimal dengan memberikan contoh sesuai hasil wawancara, akan tetapi dia tidak bisa memberikan contoh yang lain karena dia terpaku hanya pada besaran pecahan yang diberikan.

Pada komponen ini, S3 sudah dapat: a) membandingkan nilai dua pecahan dengan melihat dari selisih pecahan dan bedanya, b) mengurutkan pecahan dengan cara yang sama dengan membandingkan dan bisa juga dengan mengubah ke bentuk desimal, c) menujukkan terdapat pecahan lain antara dua pecahan akan tetapi belum bisa memberikan contoh yang tepat karena dia tidak mengetahui bahwa terdapat banyak pecahan lain di antara dua pecahan. Namun, S3 tidak dapat menunjukkan nilai tempat dan bilangan karena belum memahami besaran relatif bilangan karena belum mengetahui bahwa 1/4 (seperempat) dan $1 / 2$ (setengah) kurang dari 1 (satu) walaupun sudah memberikan definisi pecahan dengan tepat yaitu bilangan yang terbagi.

Berdasarkan hasil pembahasan, ketiga subjek memahami dengan baik arti pecahan, mengurutkan dan membandingkan pecahan pada konsep bilangan. Temuan ini sejalan dengan penelitian (Hidayat dan Budiarto, 2014) bahwa siswa dengan kemampuan matematika rendah pada komponen konsep bilangan belum bisa mengubah pecahan ke desimal, begitupun sebaliknya.

\section{Representasi urutan bilangan}

Berikut ini hasil penyelesaian soal 2 dan cuplikan wawancara S1, S2, dan S3 pada aspek kemampuan memahami representasi urutan bilangan. 


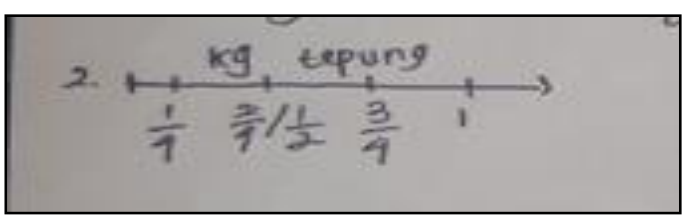

Gambar 4. Jawaban S1 terhadap soal 2

Cuplikan transkip wawancara terbadap $S 1$ terkait soal 2

P : "Bagaimana adik meletakkan 1/4 dan 1/2 pada garis bilangan?"

S1: "Karena semakin ke kiri nilainya akan semakin kecil dan semakin ke kanan nilainya akan semakin besar. Jadi 1/4 kan bagian terkecil dari soal sehingga ditaruh di bagian kiri."

$P$ : "Kenapa bisa menarub 3/4 di antara 1/2 dan 1?"

S1: "Karena kan 1/2 itu sama dengan 2/4, jadi jika diurutkan dimulai dari 1/4, 2/4, 3/4, 1 karena jika 1 dibagi menjadi 4 pasti lebih besar $3 / 4$ dari pada 2/4."

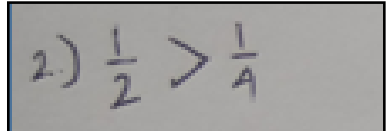

Gambar 5. Jawaban S2 terhadap soal 2

Cuplikan transkip wawancara terbadap $S 2$ terkait soal 2

$P$ : "Kenapa jawaban nomor 2 seperti ini?"

S2: "Gak tau yang nomor 2 kak."

$P$ : "Sudah lupa ya garis bilangan seperti apa?"

S2: "Hehe..."

$P$ : "Dari mana adik tahu lebih besar 1/2?"

S2: "Karena 1 itu dibagi 1/2, kalau didesimalkan jadinya 0,5 dan 1/4 itu 0,25. 0,5 itu mendekati angka 1 karena itu 0, 5 lebih besar."

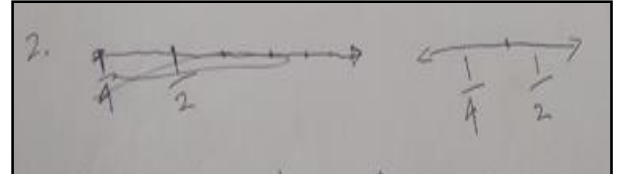

Gambar 6. Jawaban S3 terhadap soal 2

Cuplikan transkip wawancara terhadap $S 3$ terkait soal 2

P : "Bagaimana adik meletakkan 1/4 dan 1/2 pada garis bilangan?"

S3 : "Karena 1/4 lebih kecil sehingga ke kiri."

$P$ : "Nah kan, adik sudah bisa mengurutkan pecahan, akan tetapi masih belum bisa meletakekan dengan tepat, kenapa dike?" 
S3 : "Masih belum ngerti kak, saya meletakean secara asal intinya saya letakekan yang lebih kecil di kiri."

$P$ : "Misalkan ada angka 1 di garis ini, letaknya di mana dike?"

S3 : "Di sebelah 1/4."

Pada komponen ini, S1 sudah dapat: a) menyatakan pecahan ke bentuk yang senilai atau ekuivalen dengan menyebutkan pecahan lain yang senilai dengan pecahan yang diberikan dan menyatkan ke dalam bentuk desimal, b) menentukan letak pecahan dalam garis bilangan dengan memberikan jawaban yang benar dan alasan yang tepat pula, yaitu dengan melihat besaran bilangan, semakin kecil semakin ke kiri letaknya dan semakin besar semakin ke kanan letaknya dan dia meletakkan $1 / 2$ tepat di tengah antara 0 dan 1 dan 1/4 tepat di tengah anatra 0 dan $1 / 2, c)$ menyatakan pecahan dengan benda dalam kehidupan sehari-hari walaupun ia masih terpaku pada soal menggunakan benda yang memiliki satuan berat dan volume, akan tetapi sudah dapat menyatakan pecahan pada wilayah yang diarsir.

Pada komponen ini, S2 sudah dapat: a) menyatakan pecahan ke bentuk yang senilai yaitu bentuk desimal, b) menyatakan pecahan dalam kehidupan sehari-hari dengan menunjuk buku sebagai gambaran suatu pecahan dengan menyatkan $1 / 2$ itu adalah buku dibagi dua dan $1 / 4$ dibagi empat. Namun, belum dapat menentukan letak pecahan pada garis bilangan karena belum bisa menggambar garis bilangan. Hal ini ertolak belakang dengan penelitian (Hidayat \& Budiarto, 2014) bahwa siswa dengan kemampuan matematika rendah pada komponen representasi urutan bilangan belum dapat menentukan letak pecahan pada garis bilangan.

Pada komponen ini, S3 sudah dapat: a) menyatakan pecahan ke bentuk yang senilai yaitu ke bentuk desimal dan persen, b) menentukan letak pecahan pada garis bilangan karena dia sudah bisa mengurutkan letak pecahan yang lebih kecil di kiri dan yang besar di kanan akan tetapi posisinya kurang tepat, artinya belum tepat meletakkan $1 / 2$ tepat di tengah antara 0 dan 1 dan $1 / 4$ tepat di tengah antara 0 dan $1 / 2$ karena dia meletakkan secara asal intinya berurutan, c) menyatakan pecahan dalam kehidupan sehari-hari dengan menunjuk keramik sebagai gambaran suatu pecahan, artinya menyatkan $1 / 2$ itu adalah keramik dibagi dua dan $1 / 4$ dibagi empat.

Pada komponen representasi urutan bilangan, S1, S2, dan S3 sejalan dengan penelitian (Suraida, Mulayati \& Chandra, 2017) bahwasannya subjek kelompok tinggi sudah cukup peka terhadap adanya representasi lain dari suatu perhitungan matematika yang melibatkan bilangan besaran. Pada indikator menyatakan pecahan pecahan dalam kehidupan seharihari, S2 dan S3 sejalan dengan penelitian (Tonra, 2018) bahwa siswa dengan kemampuan matematika dan gaya kognitif visualiver tinggi cenderung menyelesaikan soal matematika dengan benda-benda visual atau gambar, misal dalam penelitiannya menggambar $1 / 2$ dengan ubin yang dibagi dua.

Pengaruh dari pengoperasian bilangan

Hidayati, at.al (2021), Profil Number Sense Siswa Berprestasi.......... 11-25 | 
Berikut ini hasil penyelesaian soal 3 dan cuplikan wawancara S1, S2, dan S3 pada aspek kemampuan memahami pengaruh dan pengoperasian bilangan.

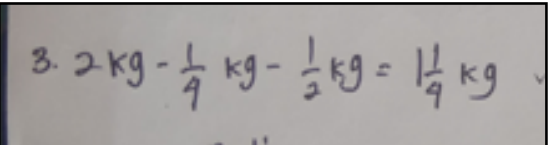

Gambar 7. Jawaban S1 terhadap soal 3

Cuplikan transkip wawancara terhadap $S 1$ terkait soal 3

$P$ : "Iika $11 / 4$ itu didesimalkan, berapa dik??"

S1 : "1, 25 kak"

$P$ : "Kenapa bisa jawab 1 1/4 kg?"

S1: "Karena kan 2 kg itu saya kurangi 1/4 sisanya $13 / 4$ kemudian lagi dikurangi 1/2 sisanya 1."

$P$ : "Kenapa 1 1/4 menggunakan operasi pengurangan?"

$S 1$ : "Tya karena kan dipakai, jadi berkurang."

$P$ : "Apakah menurut adik jawaban itu masuk akal?"

S1: "Iya kak, karena keterangan soal sudah jelas."

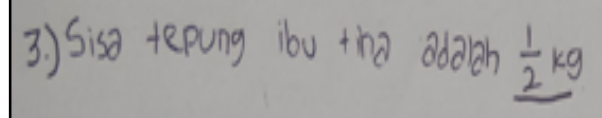

Gambar 7. Jawaban S2 terhadap soal 3

Cuplikan transkip wawancara terbadap S2 terkait soal 3

$P$ : "Kenapa menjawab sisa tepung bu Tina adalab $1 / 2$ kg?"

S2 : "Karena di $2 \mathrm{~kg}$ itu saya bitung dulu rotinya. Roti kan memerlukan 1/2 kg kak, terus kalau kita kurangi 2 kg itu dengan 1/2, maka sisanya $1 \mathrm{~kg}$. Kemudian bolu itu kan memerlukan 1/4, terus $1 \mathrm{~kg}$ itu saya kurangi 1/4. 1/4kalau didesimalkan 0, 5, terus 1 dikurangi 0, 5 itu kan hasilnya $1 / 2$.

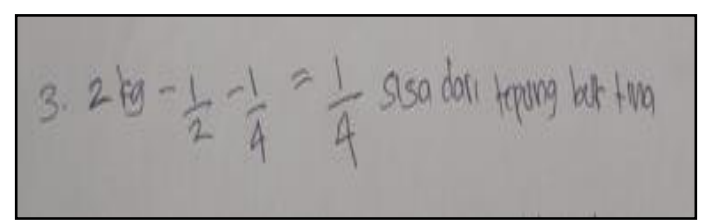

Gambar 9. Jawaban S3 terhadap soal 3

Cuplikan transkip wawancara terbadap $S 3$ terkait soal 3

$P$ : "Kenapa jawaban adik 1/4?"

S3: "Karena kan $2 \mathrm{~kg}$ dikurangi $1 / 2$ sama dengan 1/2, lagi dikurangi $1 / 4$ sama dengan 1/4, eh kak salah saya kira $1 \mathrm{~kg}$ bukan 2 kg." 
Pada komponen ini, S1 sudah dapat: a) mengemukakan akibat operasi dua bilangan yang melibatkan pecahan maupun desimal karena menggunakan operasi yang tepat dan jawaban yang benar pada soal yang diberikan, b) menilai apakah bilangan sebagai hasil operasi masuk akal dengan memberikan jawaban yang benar dan sesuai hasil wawancara, S1 sudah dapat secara langsung memberikan jawaban tanpa perhitungan di kertas.

Pada komponen ini, S2 sudah belum dapat: a) mengemukakan akibat dari operasi pada dua bilangan yang melibatkan pecahan atau desimal karena menggunakan operasi yang tepat akan tetapi belum bisa memberikan jawaban yang benar, b) menilai apakah bilangan sebagai hasil operasi yang diperoleh masuk akal meskipun dia bisa memberikan alasan yang membuat dia yakin akan jawabannya walaupun jawabannya kurang tepat.

Pada komponen ini, S3 belum dapat: a) mengemukakan akibat dari operasi pada dua bilangan yang melibatkan pecahan atau desimal karena menggunakan operasi yang tepat akan tetapi belum bisa memberikan jawaban yang benar karena kurang memperhatikan insformasi yang diketahui, b) menilai apakah bilangan sebagai hasil operasi yang diperoleh masuk akal karena dia bisa memberikan alasan yang membuat dia yakin akan jawabannya walaupun jawabannya kurang tepat.

Pada komponen pengaruh dari pengoperasian bilangan, S2 dan S3 belum dikatakan berhasil walapun memahami pengaruh dari pengoperasi sesuai dengan penelitian (Tonra, 2016) yang manyatakan bahwa walaupun siswa paham mengenai arti pecahan dan pengaruh operasi, namun hasil dari penyelesaian soal matematika yang diberikan tidak benar, maka tetap dikatakan tidak berhasil.

Pernyataan yang setara

Berikut ini hasil penyelesaian soal 4 dan cuplikan wawancara S1, S2, dan S3 pada aspek kemampuan memahami pernyataan yang setara.

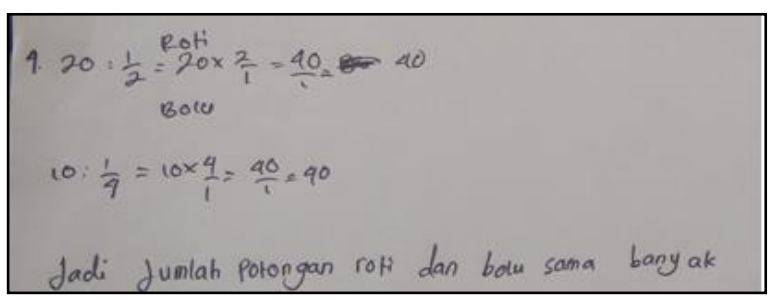

Gambar 10. Jawaban S1 terhadap soal 4

Cuplikan transkip wawancara terbadap $S 1$ terkait soal 4

$P$ : "Kenapa adik menjawab jumlah potongan roti dan bolu sama?"

S1: "Karena kan yang 1 roti itu dibagi 1/2, jadi saya menggunakan cara mudahnya saja 20 dibagi

$1 / 2$ dengan cara langsung saja mengalikan dengan pecahannya."

$P$ : "Berarti maksud adik, 20:1/2 itu sama dengan $20 \times 2$ ?"

S1 : "Iya kak."

$P$ : "Misalkan $20: 1 / 3$, itu berapa dik?"

S1 : "60 kak, $20 \times 3 . "$

Hidayati, at.al (2021), Profil Number Sense Siswa Berprestasi. $|11-25|$ 
$P$ : "Strategi menghitung apakah yang paling mudah menurut adik dalam menyelesaikan berbagai soal pecahan (menghitung di kertas, estimasi/ mengira, perbitungan mental)?"

S1: "Tergantung soalnya kak, kalau rumit pakai kertas, tapi kalau soal yang ini semua pake nalar kecuali nomor 3."

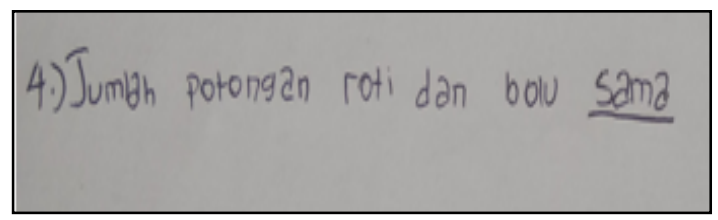

Gambar 11. Jawaban S2 terhadap soal 4

Cuplikan transkip wawancara terhadap S2 terkait soal 4

$P$ : "Kenapa adik bisa menjawab jumlah potongan rotidan bolu itu sama?"

S2 : "Karena masing-masing roti dipotong 2, jadi ada 2 bagian setiap roti, terus kan jumlab rotinya ada 20 dipotong 2, lalu 2 itu saya kalikan 20. Kalau bolu kan 1/4, terus ada 10 bolu yang setiap bolu dipotong 4, jadinya ada 4 potong setiap bolu, karena bolunya ada 10, maka 4 itu saya kalikan 10. Jadi, jumalah potongan roti dan bolu sama."

$P$ : "Berarti, 20:1/2 itu sama 20 di kali?"

S2 : "mmmm," (bingung, kemudian menjelaskan ulang)

$P$ : "Strategi menghitung apakah yang paling mudah menurut adik dalam menyelesaikan berbagai soal pecahan (menghitung di kertas, estimasi/ mengira, perbitungan mental)?"

S2 : "Lebih suka mengira-ngira kak, tapi tetap menggunakan kertas sebagai pembuktian."

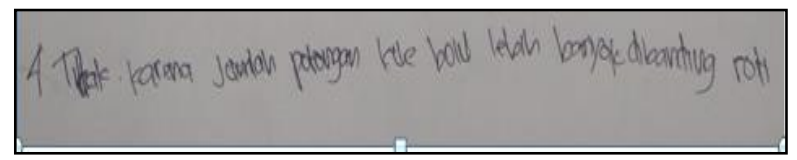

Gambar 11. Jawaban S3 terhadap soal 4

Cuplikan transkip wawancara terbadap $S 3$ terkait soal 4

$P$ : "Kenapa jawaban adik jumalah potongan roti dan bolu tidak sama?"

S3: "Karena kan rotinya dipotong 1/2, otomatis menjadi lebih kecil atau sedikit begitupun bolu jika potong $1 / 4$ akan menjadi lebib banyak."

$P$ : "Coba perbatikan ulang soal, diketahui 20 buah roti yang akan dipotong 1/2."

S3 : "40 kak."

$P$ : "Kalau 10 dibagi 1/4?"

S3 : "Sama, sama jadinya kak, 20 dipotong 1/2 sama dengan 40 dan 10 dipotong 1/4 sama dengan 40 juga."

$P$ : "Lalu, apa pendapat adik tentang pernryataan 20:1/2?"

S3: "1 roti dibagi $1 / 2$ itu kan 1/2, terus kalau 20 dibagi 1/2 itu kan 10 yaitu setengabnya dari 20."

$P$ : "Strategi menghitung apakah yang paling mudah menurut adik dalam menyelesaikan berbagai soal pecahan (menghitung di kertas, estimasi/mengira, perbitungan mental)?" 


\section{S3 : "Pakai kertas kak, kalau mengira-ngira suka salah."}

Pada komponen ini, S1 sudah dapat menentukan pernyataan yang setara dengan pernyataan yang diberikan serta dengan jawaban dan alasan yang benar pula. Pernyataan ini sejalan dengan hasil penelitian (Hidayat \& Budiarto, 2014) bahwa siswa dengan kemampuan matematika tinggi sudah mampu menjawab soal pernyataan setara dengan jawaban dan alasan yang benar.

Pada komponen ini, S2 belum dapat menentukan pernyataan yang setara dengan pernyataan yang diberikan dalam bentuk tertulis, artinya dia belum mengetahui bahwa 20 : $1 / 2$ sama dengan $20 \times 2$ akan tetapi jawaban dan alasan yang diberikan sudah tepat, yaitu menggunakan cara yang lebih sederhana dengan melihat bahwa masing-masing roti dipotong 2, jadi setiap roti ada 2 potong, sehingga untuk jumlah potongan roti 20 dikali 2. Begitu pula dengan bolu, setiap bolu ada 4 potong roti, sehingga jumlah potongan bolu 10 dikali 4. Jadi, jumlah potongan bolu dan roti sama, yaitu 40 potong.

Pada komponen ini, S3 belum dapat menentukan pernyataan yang setara dengan pernyataan yang diberikan dalam bentuk tertulis, artinya dia belum mengetahui bahwa 20 : $1 / 2$ sama dengan $20 \times 2$ dan belum bisa memberikan jawaban yang benar serta alasan yang diberikan kurang jelas. Temuan ini sejalan dengan hasil penelitian (Suraida, Mulayati \& Chandra, 2017) yang menyatakan bahwa subjek kelompok tinggi belum dapat secara langsung melihat hubungan antara dampak atau karakteristik suatu operasi bilangan dalam melakukan (perkiraan) perhitungan. Subjek memahami hubungan dari dampak suatu operasi tetapi tidak dapat secara langsung menghubungkan masalah tersebut dengan masalah yang diberikan.

\section{Perbitungan dan strategi menghitung}

Pada komponen ini, S1, S2, dan S3 dalam mengerjakan soal, rata-rata lebih menggunakan nalar walaupun tetap menggunakan kertas sebagai oretan dan melihat kebenaran hasil yang diperoleh. S1 menggunakan strategi menghitung dalam suatu masalah matematika tergantung dari tingkat kerumitan soal. Untuk soal TNS dalam peneltian ini, S1 cenderung menggunakan nalar dan estimasi. S2 cenderung lebih suka menggunakan estimasi walaupun tetap melakukan perhitungan di kertas. Sedangkan S3 lebih yakin menggunakan perhitungan di kertas karena ketika menggunakan estimasi suka salah. Seperti halnya dalam penelitian (Amirullah \& Budiarto, 2013) bahwa perhitungan dan strategi menghitung merupakan suatu kemampuan yang mencakup aplikasi variasi dari komponen number sense yang sebelumnya dideskripsikan ke dalam perumusan dan implementasi dari proses penyelesaian untuk menghitung dan perhitungan. Misalnya dengan menggunakan perhitungan mental, estimasi, kertas/pensil, atau kalkulator.

Berdasarkan hasil pembahasan, siswa sudah memahami number sense pada konsep bilangan dan representasi urutan bilangan dengan baik, hanya saja pada aspek menunjukkan pecahan lain diantara dua pecahan masih membatasi dan masih belum bisa 
meletakkan pecahan dengan tepat pada garis bilangan bahkan belum bisa menggambar garis bilangan. Sehingga dalam proses pembelajaran, ada baiknya untuk lebih mendalami pemahaman siswa terhadap pecahan dalam garis bilangan tentang urutan dan kerapatan bilangan. Sedangkan untuk komponen pengaruh dari pengoperasin bilangan dan pernyataan yang setara masih banyak indikator yang belum terpenuhi terutama pada mengetahui akibat dari pengoperasian pecahan dan menemukan pernyataan setara dengan pernyataan yang diberikan.

\section{Kesimpulan}

Berdasarkan hasil analisis dan pembahasan, profil number sense siswa berprestasi sekolah menengah pertama dengan nilai matematika tinggi pada materi pecahan dalam kategori cuku baik karena semua komponen sudah terpenuhi. Namun demikian ada beberapa indikator pada masing-masing komponen belum terpenuhi. Adapun deskrispsi number sense siswa pada setiap komponen meliputi: 1) pada komponen konsep bilangan, ketiga subjek sudah memahami dengan baik indikator menunjukkan arti pecahan, membandingkan dan mengurutkan pecahan, walaupun S1 belum bisa menunjukkan terdapat pecahan lain atara dua pecahan dan S2 belum bisa menunjukkan nilai tempat bilangan; 2) pada komponen representasi bilangan, ketiga subjek sudah memahami dengan baik menyatakan pecahan ke bentuk lain yang senilai serta menyatakan pecahan ke wilayah yang diarsir, gambar, dan sejenisnya, walaupun S1 belum bisa menentukan letak pecahan pada garis bilangan; 3) pada komponen pengaruh dari pengoperasian bilangan, S1 dari subjek sudah memahami dengan baik indikator menemukan akibat dari operasi pada dua pecahan dan menilai kewajaran hasil, sedangkan S1 dan S2 belum memhami dengan baik pengaruh dari pengoperasian bilangan; 4) pada komponen pernyataan yang setara, S1 sudah memahami dengan baik indikator mengenal, menentukan, dan menyederhanakan pernyataan setara dengan pernyataan yang diberikan. Sedangkan S2 belum bisa memodelkan ke dalam pernyataan matematika, dan S3 masih belum memahami pernyataan yang setara; dan 5) pada komponen perhitungan dan strategi menghitung, ketiga subjek sudah menggunakan strategi sesuai kecendenrungan masing-masing. S1 dan S2 cenderung nalar dan estimasi, sedangkan S3 cenderung menggunakan perhitungan di kertas.

\section{Referensi}

Amirullah, A. F. \& Budiarto, M. T. (2013). "Kemampuan Number Sense Siswa KelasVII SMP Dilihat dari Perbedaan Jenis Kelamin". MATHEdunesa, 2(1).

Arhamni, Johar, R. \& Abidin, Z. (2015). "Analisis Strategi Number Sense Siswa SMKNegeri Penerbangan Aceh". Jurnal Pendidikan Matematika, 9(1), 94-245. 
Gulbacgci, H. \& Sengul, S. (2012). "Evaluation of Number Sense on the Suject of Secondary Stage Student in Turkey". Internasional Online Journal of Educational Sciences, 4(2), 296310

Gunawan, I. (2013). Metode Penelitian Kualitatif, Jakarta: PT. Bumi Aksara.

Hidayat, G. W., 2014 \& Budiarto, M. T. (2014). "Profil Kemampuan Number Sense Siswa Kelas VII SMP dalam Menyelesaikan Masalah Matematika Ditinjau dari Perbedaan Kemampuan Matematika". Jurnal Ilmiah Pendidikan Matematika, 3(3), 79-87. Doi: https://doi.org/10.26740/mathedunesa.v3n3.p\%25p

Jannah, M. (2014). "Analisis Faktor Penyebab Peserta Didik dengan Kecerdasan Intelegensi (IQ) Tinggi Memperoleh Hasil Belajar Matematika Rendah”, (Naskah Publikasi: Universitas Mubammadiyah Surakarta).

McIntosh, A., Reys, B. J., \& Reys, R. E. (1992). A proposed framework for examining basic number sense. For the learning of mathematics, 12(3), 2-44.

Miles, M. B., Huberman, A. M., \& Saldana, J. (2014). Qualitative data analysis: A methods sourcebook (3rd ed.). SAGE Publications, Inc.

Mufidah, I. (2017). "Profil Number Sense Siswa SD pada Materi Pecaban Ditinjau dari Gaya Kognitif Object Imagery, Spatial Imagery, dan Verbal'. Jurnal Matematika Kreatif-Inovatif, $8(2), 208-214$

Putrawangsa, S., \& Hasanah, U. (2018). Strategi dan tingkat kepekaan bilangan siswa sekolah dasar dalam menyelesaikan masalah operasi bilangan bulat. Jurnal Pendidikan Matematika, 12(1), 15-28.

Suraida, A., Mulyati, S., \& Chandra, T. D. (2017). "Kemampuan Number Sense Siswa Sekolah Menengah Pertama Kelas VII pada Materi Pecahan”, Prosidding SI MaNis (Seminar Nasional Integrasi Matematika dan Nilai Islami), 1(1), 274-275

Tonra, W. S. (2018). "Profil Number Sense Siswa Bergaya Kognitif Visualizer terhadap Makna Pecahan Desimal". Beta: Jurnal Tadris Matematika, 11(1), 20-36

Tonra, W. S. (2016). "Pembelajaran Number Sense untuk Meningkatkan Hasil Belajar Siswa Sekolah Dasar pada Materi Pecahan", Jurnal Matematika dan Pendidikan Matematika, 5(2), 2541-2906

Widoyoko, E. P. (2014). Teknik Penyusunan Instrumen Penelitian, Yogyakarta: Pustaka Belajar.

Witri, G, Putra, Z. H. \& Nurhanida. (2015). "Analisis Kemampuan Number Sense Siswa Sekolah Dasar Di Pekanbaru". Proceeding: $7^{\text {th }}$ Internasional Seminar on Regional Education, 2, 755-761

Yapici, A., \& Altay, M. K. (2017). An Investigation of Middle School Students' Number Sense Regarding the Percent. Abant İzet Baysal Üniversitesi Eğitim Fakültesi Derg, 17(4), 2221-2243. 